\title{
Fatty Acid Profiles of Serum Lipids in Subjects Ingesting Fats on Different Melting Points
}

\author{
Pyata SRINIVASARAO* and Indushekhar SHENOLIKAR \\ National Institute of Nutrition, Indian Council of Medical Research, \\ Jamai Osmania P.O., Hyderabad-500 007, India
}

(Received May 16, 1990)

\begin{abstract}
Summary In an attempt to ascertain the relative utilization of hydrogenated fats with different melting points, we conducted studies on healthy male volunteers maintained on a diet containing peanut oil (control) or hydrogenated fats melting at $37^{\circ}, 41^{\circ}$, or $45^{\circ} \mathrm{C}$. The results indicated a significantly higher excretion of fecal fat during the ingestion of the fat melting at $45^{\circ} \mathrm{C}$. During these dietary regimen, serum triglycerides as well as serum cholesterol tended to increase with an increase in the melting point of the dietary fat. Fatty acid profile of serum lipids showed a decreasing trend in the concentration of linoleic acid $(18: 2)$ and an increase in that of arachidonic acid in response to ingestion of highmelting point fat. These investigations point to the fact that high-melting point hydrogenated fats are not only poorly absorbed but also influence fatty acid metabolism. These results are discussed in the light of trans fatty acids of dietary fats.
\end{abstract}

Key Words: high-melting point fats, serum lipids, fatty acids

Selective hydrogenation and blending of edible oils have been in vogue in the vanaspathi manufacturing industry in India. The modified processing adopted by the manufacturers results in fats of different and higher melting points for human consumption. Earlier studies carried out at this Institute [1] indicated that high-melting point fats not only offer a greasy feeling to the palate but also cause negative nitrogen balance and are poorly absorbed. Since trans fatty acids predominate in these fats due to hydrogenation, it is reasonable to assume that highmelting point fats could alter lipid metabolism. The present investigation was therefore undertaken to ascertain the relative absorption of hydrogenated fats with varying melting points and to study their effects on serum lipids and fatty acid

*To whom correspondence should be addressed. 
profiles in human subjects. The data were compared with those from control subjects who ingested peanut oil.

\section{MATERIALS AND METHODS}

Four healthy adult male volunteers received diets containing fats of different melting points and peanut oil as the control. The nutrient composition of the diets was otherwise similar, and each provided $2,100 \mathrm{kcal}$. The fat, which constituted 35 $\mathrm{g}$ of the diet, consisted of either refined peanut oil or hydrogenated fat with specific melting point supplied by $\mathrm{M} / \mathrm{s}$ Hindustan Lever Ltd., Bombay, India. The melting points of the hydrogenated fats were $37^{\circ}, 41^{\circ}$, and $45^{\circ} \mathrm{C}$. Characteristics of these fats such as acid value, iodine value, saponification value, unsaponifiable matter, and fatty acid composition were determined.

Each subject was kept on different fat diet following the random block experimental design. A stabilization period of 17 days on each fat regimen was allowed, after which period feces were collected for 3, $24 \mathrm{~h}$ periods, dried, and estimated gravimetrically for fat content. Body weights of the subjects were recorded and the blood was drawn and serum separated in each case. The details of the investigations are reported elsewhere [1].

Serum lipids were extracted by the method of Folch et al. [2]. Total cholesterol and triglycerides were determined by the methods of Zlatkis et al. [3] and Lowell and Ralph [4], respectively. Aliquots of total lipids were subjected to methanolysis and transesterification [5]. Resulting methyl esters were analyzed in a Varian model 3700 gas chromatograph fitted with a flame ionization detector in a column containing $15 \%$ polydiethylene glycol succinate coated on chromosorb w. as the stationary phase.

All the chemicals used were of analytical grade, and standard fatty acid methyl esters were from Sigma Chemical Company, St. Louis, MO.

\section{RESULTS AND DISCUSSION}

The chemical nature of the different fats consumed by the subjects is depicted in Table 1. Fatty acid profiles (Table 2) of hydrogenated fats indicated greater proportions of palmitic (16:0) and stearic (18:0) acids and an absolute loss of linoleic acid $(18: 2)$ in the case of fats melting at $41^{\circ}$ and $45^{\circ} \mathrm{C}$.

Fecal fat excretion either in absolute terms or expressed as percent of total fat intake significantly increased in the case of hydrogenated fat with a melting point of $45^{\circ} \mathrm{C}$ compared with other fats (Table 3 ). Thus the absorption of fat melting at $45^{\circ} \mathrm{C}$ was impaired.

Serum cholesterol and triglycerides showed higher values on hydrogenated fat regimen compared with the peanut oil values. However, serum cholesterol and triglycerides tended to increase with increasing melting point of fats (Table 4).

The fatty acid profiles of total lipids in serum of subjects maintained on 
Table 1. Characteristics of fats.

\begin{tabular}{lcccc}
\hline & $\begin{array}{c}\text { Peanut oil } \\
\text { (PNO) }\end{array}$ & $37^{\circ} \mathrm{C}$ & $41^{\circ} \mathrm{C}$ & $45^{\circ} \mathrm{C}$ \\
\hline Slip melting point $\left({ }^{\circ} \mathrm{C}\right)$ & - & $34-35$ & $41-42$ & $45-46$ \\
Acid value & 0.85 & 1.26 & 1.48 & 1.54 \\
Iodine value & 94.5 & 65.0 & 59.6 & 51.0 \\
Saponification value & 188.7 & 176.6 & 175.8 & 174.3 \\
Unsaponifiable matter (\%) & 0.35 & 0.33 & 0.49 & 0.38 \\
\hline
\end{tabular}

Table 2. Fatty acid profile of fats.

\begin{tabular}{lcrrr}
\hline \multirow{2}{*}{ Fatty acid } & \multicolumn{5}{c}{ Fats } \\
\cline { 2 - 5 } & PNO & $37^{\circ} \mathrm{C}$ & $41^{\circ} \mathrm{C}$ & $45^{\circ} \mathrm{C}$ \\
\hline $14: 0$ & - & - & 0.9 & 1.1 \\
$16: 0$ & 8.7 & 15.4 & 29.0 & 26.3 \\
$16: 1$ & 0.9 & - & - & - \\
$18: 0$ & 4.6 & 3.0 & 8.9 & 20.8 \\
$18: 1$ & 56.4 & 44.6 & 54.0 & 50.8 \\
$18: 2$ & 23.2 & 31.8 & - & - \\
$18: 3-20: 0$ & 3.0 & 1.2 & 0.9 & - \\
$20: 0$ & 3.2 & 4.0 & 6.3 & 1.0 \\
\hline
\end{tabular}

Values are percentages of total fatty acid methyl esters.

Table 3. Fecal fat excretion on different fat regimens.

\begin{tabular}{lcccc}
\hline & \multicolumn{4}{c}{ Total quantity } \\
\cline { 2 - 5 } & PNO & $37^{\circ} \mathrm{C}$ & $41^{\circ} \mathrm{C}$ per day & $45^{\circ} \mathrm{C}$ \\
\cline { 2 - 5 } & $4.6 \pm 0.41$ & $4.3 \pm 0.29$ & $4.8 \pm 0.72$ & $7.7^{*} \pm 1.09$ \\
\hline Mean \pm SE & $(12.7)$ & $(12.3)$ & $(13.2)$ & $(21.2)$ \\
\hline
\end{tabular}

Values in parenthesis indicate fat excretion as percent of intake. ${ }^{*}$ Significantly higher, $p<0.01$.

Table 4. Cholesterol and triglycerides in serum.

\begin{tabular}{lcccc}
\hline & PNO & $\begin{array}{c}37^{\circ} \mathrm{C} \\
(\mathrm{mg} / \mathrm{dl}\end{array}$ & $\begin{array}{c}41^{\circ} \mathrm{C} \\
(\text { Mean } \pm \mathrm{SE}))\end{array}$ & $45^{\circ} \mathrm{C}$ \\
\hline Cholesterol & $151 \pm 22.2$ & $186 \pm 21.3$ & $186 \pm 16.5$ & $193 \pm 13.4$ \\
Triglycerides & $177 \pm 23.6$ & $229 \pm 86.1$ & $258 \pm 30.0$ & $264 \pm 68.9$ \\
\hline
\end{tabular}

different fat diets (Table 5) indicated that palmitic, oleic, and linoleic acids constituted the major portion of total fatty acids, irrespective of the nature of the dietary fat. Although linoleic acid tended to decrease and arachidonic acid tended to increase with the increase in the melting point of fat consumed, these changes were not significant statistically because of individual variation. The relative 
Table 5. Fatty acid profile of serum lipids in subjects on different dietary fats.

\begin{tabular}{|c|c|c|c|c|}
\hline & PNO & $37^{\circ} \mathrm{C}$ & $41^{\circ} \mathrm{C}$ & $45^{\circ} \mathrm{C}$ \\
\hline & \multicolumn{4}{|c|}{$($ Mean values $\pm S E)$} \\
\hline$<16$ & $0.9 \pm 0.25$ & $0.8 \pm 1.08$ & $0.8 \pm 0.05$ & $1.3 \pm 0.13$ \\
\hline $16: 0$ & $21.3 \pm 2.32$ & $18.8 \pm 4.08$ & $16.6 \pm 1.88$ & $17.9 \pm 1.52$ \\
\hline $16: 1$ & $4.9 \pm 0.67$ & $3.4 \pm 1.10$ & $7.3 \pm 1.41$ & $5.4 \pm 0.46$ \\
\hline $18: 0$ & $4.9 \pm 1.87$ & $7.6 \pm 3.74$ & $3.9 \pm 1.44$ & $5.9 \pm 1.03$ \\
\hline $18: 1$ & $26.3 \pm 1.77$ & $25.6 \pm 0.27$ & $28.5 \pm 3.67$ & $27.0 \pm 0.93$ \\
\hline $18: 2$ & $26.0 \pm 1.49$ & $20.4 \pm 1.81$ & $19.6 \pm 2.18^{*}$ & $17.5 \pm 4.29^{*}$ \\
\hline $18: 3$ or $20: 0$ & $3.9 \pm 2.14$ & $2.5 \pm 0.46$ & $2.5 \pm 0.66$ & $5.0 \pm 2.22$ \\
\hline $20: 4$ & $7.2 \pm 2.34$ & $12.0 \pm 2.71$ & $9.2 \pm 3.26$ & $14.0 \pm 3.95^{*}$ \\
\hline $22: 0$ & $4.6 \pm 3.09$ & $8.9 \pm 2.58$ & $11.6 \pm 5.90$ & $6.0 \pm 3.59$ \\
\hline
\end{tabular}

Values are expressed as percent of total fatty acid methyl esters. ${ }^{*}$ Though values are different from the value of PNO they are not statistically significant.

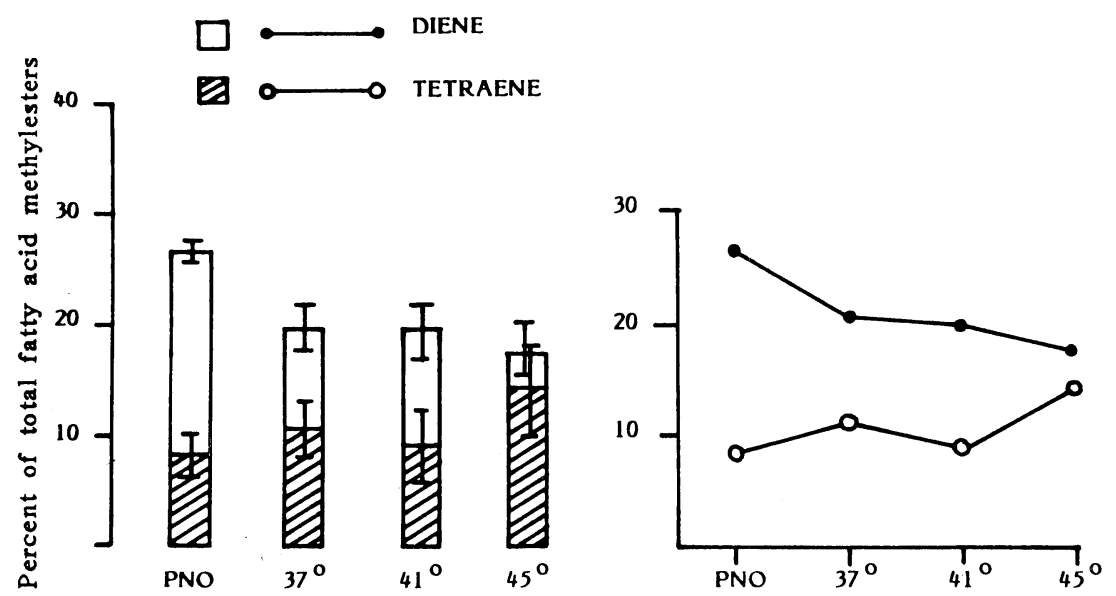

Fig. 1. Relative levels of diene (open bars) and tetraene (hatched bars) fatty acids in serum of subjects ingesting PNO (peanut oil) or hydrogenated fats with slip points of $37^{\circ}, 41^{\circ}$, and $45^{\circ} \mathrm{C}$. Bars represent percent of total fatty acid methyl esters and show the mean \pm SE of 4 observations.

proportions of dienes and tetraenes of serum lipids with respect to different melting point fats are more clearly depicted in Fig. 1. The results suggest that the serum lipid pattern to a certain extent undergoes qualitative changes as a result of consumption of fats that are modified in their physical characteristics. Altered melting point is one such modification. The decreased proportion of linoleic acid in subjects could be the result of consumption of high-melting point hydrogenated fats, which are known to be deficient in this essential fatty acid (Table 2).

The higher levels of arachidonic acid in the subjects on a high-melting point fat regimen points to possibly lesser utilization of this fatty acid precursor for prostaglandin synthesis. The process of hydrogenation further modified the nature 
of fat by substituting 'trans' isomers for 'cis' oriented fatty acids. It is known [68] that high levels of dietary trans fatty acids induce changes in the content and metabolism of polyunsaturated fatty acids. In view of the increasing trend towards use of hydrogenated vegetable oils and the possibility of trans fatty acids influencing cholesterol dynamics [9] and synthesis of physiologically active prostaglandin and related substances [10], further research is necessary to ascertain the alterations in metabolic processes as a result of hydrogenated fat consumption. The present studies, however, indicate poorer absorption and inefficient utilization of the fats melting at higher than $41{ }^{\circ} \mathrm{C}$ as judged by higher fecal fat excretion and alterations in serum fatty acid profiles in subjects consuming these fats.

Authors are grateful to Dr. Vinodini Reddy, Director, National Institute of Nutrition, Hyderabad, for her keen interest in the work. Thanks are due to Mrs. Padmini Prakash and Mrs. Indumathi Reddy for their technical assistance.

\section{REFERENCES}

1. Shenolikar, I.S., and Tulpule, P.G. (1981): The effect of melting point of fat on its digestibility and interaction with other nutrients. Proceedings of International Conference on "Palm Oil Product Technology in the Eighties," pp. 1-8.

2. Folch, J., Lees, M., and Sloane-Stanley, G.H. (1957): A simple method for isolation and purification of total lipids from animal tissues. J. Biol. Chem., 226, 497-509.

3. Zlatkis, A., Zak, B., and Boyle, A.J. (1953): A new method for the direct determination of serum cholesterol. J. Lab. Clin. Med., 41, 486-492.

4. Lowell, B.F., and Ralph, T.D. (1973): Stable reagents for determination of serum triglycerides by a colorimetric Hantzch condensation method. Clin. Chem., 19, 338-340.

5. Kishimoto, Y., and Hoshi, M. (1972): Isolation, purification, and assay of fatty acids and steroids from the nervous system, in Methods of Neurochemistry, ed. by Fried, R., Marcel Dekker Inc., New York, pp. 81-84.

6. Holman, R.T. (1951): Metabolism of isomers of linoleic and linolenic acids. Proc. Soc. Exp. Biol. Med., 76, 100-102.

7. Egwin, P.O., and Kummerow, F.A. (1972): Incorporation and distribution of dietary elaidate in the major lipid classes of rat heart and plasma lipoproteins. J. Nutr., 102, 783792.

8. Guo, L.S.S., and Alexander, J.C. (1974): Comparative studies on composition of liver phospholipids from rats fed oleic or elaidic acid. Nutr. Metab., 16, 51-63.

9. Sugano, M.K., Kuko, R., and Takashi, J. (1984): Cholesterol dynamics in rats fed cis and trans-octadecenoate in the form of triglyceride. J. Lipid Res., 25, 474-485.

10. Kinsella, J.E., Bruckner, G., Mai, J., Shimp, J. (1981): Metabolism of trans fatty acids with emphasis on the effects of trans, trans octadecadienoate on lipid composition, essential fatty acids and prostaglandins: An overview. Am. J. Clin. Nutr., 34, 2307-2318. 